\title{
Tropical cyclones characteristic in southern Indonesia and the impact on extreme rainfall event
}

\author{
Erwin Mulyana ${ }^{1, *}$, M. Bayu Rizky Prayoga ${ }^{1}$, Ardila Yananto $^{1}$, Samba Wirahma ${ }^{1}$, Edvin Aldrian ${ }^{1}$, Budi Harsoyo $^{1}$, Tri \\ Handoko Seto ${ }^{1}$, and Yaya Sunarya ${ }^{1}$
}

${ }^{1}$ Agency for the Assessment and Application of Technology, PUSPIPTEK Area, Serpong, South Tangerang, 15314, Indonesia

\begin{abstract}
The southern region of Indonesia is one of the places where tropical cyclones grow in the southern hemisphere. During 1983-2017 there were 51 tropical cyclones occurring in the region. This study aims to understand the characteristic of tropical cyclones in southern Indonesia and their variations, both spatially and temporally, and their effect on extreme rain events in Indonesia. Historical data analysis results show that tropical cyclones in southern Indonesia generally occur in November-April with a lifetime of 7-8 days. The result of data analysis shows that the central pressure value of tropical cyclone in latitude $0^{\circ}-10^{\circ} \mathrm{S}$ is more than $960 \mathrm{hPa}$. The value tends to be higher than the central value pressure of tropical cyclone in latitude $10^{\circ} \mathrm{S}-20^{\circ} \mathrm{S}$, which has the range of values about $920-960 \mathrm{hPa}$. This study also explains that there are 9 tropical cyclones in 35 years back that grow or move closer to the Indonesian archipelago in latitude $0^{\circ}-10^{\circ} \mathrm{S}$. The event of tropical cyclone Dahlia at the end of 2017 also affect the enormously increase of rainfall in Gunungkidul, Yogyakarta region with the increase of rain reaches $750 \%$ from the historical average.
\end{abstract}

\section{Introduction}

One of the tropical cyclone growth areas that lie close to Indonesia is the southeast Indian Ocean. The average growth of tropical cyclones in this region is only 7 (seven) incidents per year or about $9 \%$ (nine percent) of the average number of tropical cyclones worldwide. Indonesia is a region that theoretically cannot be crossed by tropical cyclones; this is due to the physical characteristics of tropical cyclones that will always move away from the equator. Though not a trajectory, tropical cyclone seeds for many south-eastern Indian Ocean basins are derived from the territorial waters of southern Indonesia.

The world's most tropical cyclone growth region is the Indian Ocean and Australia's western waters. As the Australian Bureau of Meteorology explained, the growth of cyclones in the region reaches an average of 10 times per year [1].

Cyclones are formed over the oceans with seasurface temperatures above $27^{\circ} \mathrm{C}$ but not formed in the 40 North Latitudes and 40 southern latitudes regions of the equator because the Coriolis force in this area is too small (close to zero).

This paper examined a long-term historical tropical cyclone period, 35 years. The same period length was also examined as in [2], in an environment of increasing sea surface temperature. A substantial increase was seen in the number and proportion of hurricanes reaching categories 4 and 5 . The most significant increase occurred in the North Pacific, Indian, and Southwest
Pacific Oceans, and the smallest percentage increase occurred in the North Atlantic Ocean. These increases have taken place while the number of cyclones and cyclone days has decreased in all basins except the North Atlantic during the past decade.

Through statistical, it has been examined that the significance of trends in tropical cyclones (TCs) in the South Indian Ocean (SIO) showed positive trends in the numbers of $945 \mathrm{hPa}$ and $950 \mathrm{hPa}$ TCs as in [3]. It is also determined that for the Australian region (AR) and the Southern Hemisphere (SH), trends of tropical cyclones with intense pressures ( $970 \mathrm{hPa}$ or lower) has increased slightly. Meanwhile, the numbers of weak pressures $(990$ $\mathrm{hPa}$ minimum) and moderate pressures (970-990 hPa) have declined [4].

In north-western Australia, which is close enough to southern Indonesia, it has been shown that there is an increasing trend of tropical cyclones central pressure during 1968-2001. However, the increasing trend tends to appear because influenced to some extent by changes in data-set quality, as in [5] and [6].

Tropical cyclone (TC) activity fluctuates depending on large-scale environmental changes caused by various atmospheric and oceanic oscillatory phenomena [7]. Across the globe, the activity of tropical cyclones peaks at the end of summer where ocean temperatures warm up. In the southern hemisphere, the activity of tropical cyclones begins at the end of October until the end of May. The peak of cyclone activity in the Southern Indian

\footnotetext{
Corresponding author: erwin.mulyana@bppt.go.id
} 
The ocean is from January to March. The warm waters of the Indian Ocean influence this cyclone activity because the sun is right above the waters of the Indian Ocean.

Generally, the formation of tropical cyclones is active above 100 north latitude and southern latitudes. Therefore, the Indonesian territory is not an area of tropical storm/cyclone formation. However its geographic position is adjacent to the formation and trajectory of tropical cyclones

In addition, although tropical cyclones are moving away from Indonesia, the remote impact of tropical cyclones still occurs in Indonesia. Indirect impacts include the presence of a wind encounter area that can cause the rain with a heavy intensity to very dense and another indirect impact is the strong wind blow.

In late 2017, there were several natural phenomena such as torrential rain and extreme winds in Indonesia. The condition was caused by the presence of tropical cyclones that pass very close to the southern territory of Indonesia (Dahlia and Cempaka). This study attempts to figure the patterns and characteristics of tropical cyclones occurring in southern Indonesia. The result of this study could give new information about the appearances of tropical cyclones in southern Indonesia and its impact on the massive rain event. The information could help us to understand whether the number of the tropical cyclone is increasing recently. By understanding that phenomena, disaster mitigation could be well-prepared during the peak of tropical cyclone season in southern Indonesia.

\section{The Material and method}

The study area is southern Indonesia to the southern latitude of $10^{\circ} \mathrm{S}$ (Fig. 1). The historical data of tropical cyclones used are tropical cyclone records from the Bureau of Meteorology of Australia (BOM), located in the southern territorial waters of Indonesia from 1983 to 2017. Temporally, the tropical cyclones data used is a tropical cyclone event in southern Indonesia which formed around November-April.
Tropical cyclones data, which was obtained from BOM before, is tabular data-set contained with information about location, pressure and time. To get a spatial picture of the data, further processing by changing the tabular into vector (spatial) data was done using GIS software so that the entire tropical cyclone within 1983-2017 could be mapped. This data processing requires attribute information such as the location of the cyclone and the time information, which is found in the initial data obtained from the BOM cyclone database. Cyclone data which contain location information is mapped by selecting the coordinate and convert them into spatial graphic through GIS operation.

As the result of GIS processing, there are no fewer than 178 tropical cyclones occurring in 1983-2017 in the southern hemisphere. The number of tropical cyclones then selected by selecting only the occurrence of tropical cyclones that grow or cross the latitude of $0^{\circ}$ to $10^{\circ}$ leaving a total of 51 tropical cyclones. Spatial data processing is performed on the tropical cyclone tracks to determine the spatial pattern of tropical cyclone growing spots. In addition, geographical processing is also done to map the central pressure by interpolating the value of TC's central pressure. The central pressure of cyclones also being reclassified to determine the strength of the tropical cyclone in southern Indonesia. This process also is done by using a GIS operation named "Reclassify."

In addition to analyzing the intensity of rainfall, the data from TRMM (Tropical Rainfall Measuring Mission) JAXA data with a spatial resolution of 0.05 degrees used in this study. TRMM JAXA gives historical from rainfall data from satellite monitoring. TRMM data is rainfall monitoring data which is collected by satellite. TRMM itself is developed by NASA (National Aeronautics and Space Administration) in cooperation with JAXA (Japan Aerospace Exploration Agency). TRMM data has been used to describe the extreme conditions of rainfall (floods) in the floods of Wasior (Papua, Indonesia) in October 2010 [8] and the flood incident in the Jakarta area in early 2013 [9] with good results. Rainfall data from TRMM JAXA in this study, is primarily used to determine the intensity of historical and actual rainfall during Cempaka Tropical Cyclone in the south coast of D.I. Yogyakarta Province in November 2017.

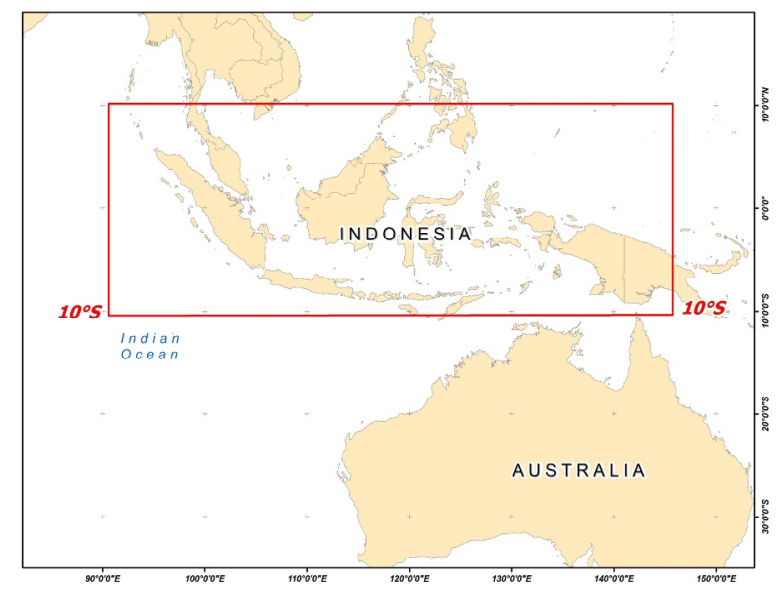

Fig. 1. Study area.

\footnotetext{
* Corresponding author: erwin.mulyana@bppt.go.id
} 


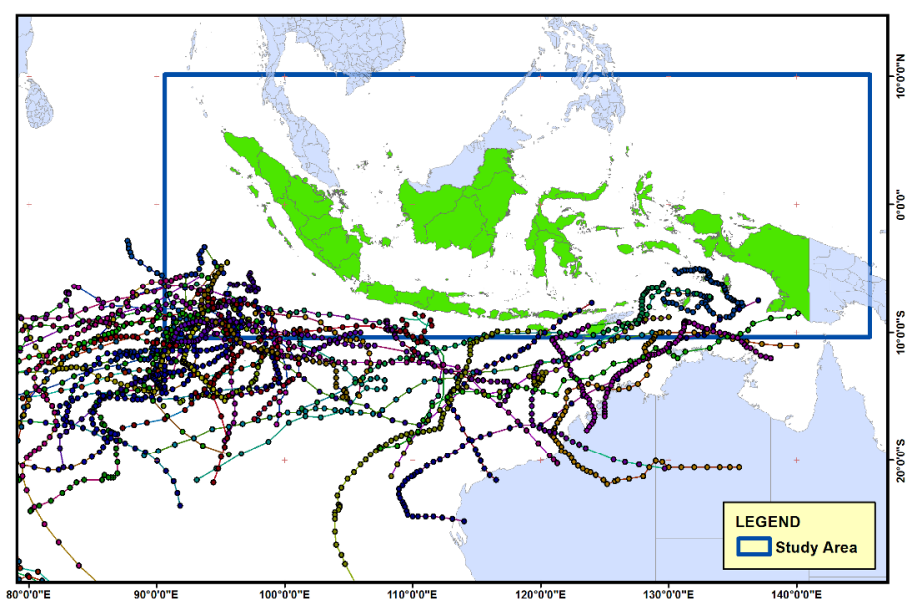

Fig. 2. The Tropical Cyclones in Southern of Indonesia from 1983-2017.

\section{Results and discussions}

In general, the occurrence of Tropical Cyclones in Southern Indonesia below 10 degrees South Latitude is difficult to establish due to the relatively small rotational power caused by the Coriolis force effect. However, during the 35-year span from 1983-2017 there at least 51 Tropical Cyclones in Southern Indonesia falling below 10 degrees Southern Latitude. The spatial distribution of the occurrence of tropical cyclones in Southern Indonesia is represented in Figure 2.

Based on Figure 2 it can be seen that the occurrence of Tropical Cyclones in Indonesia mostly occurs in the Southwest, especially in the Indian Ocean. The occurrence of Tropical Cyclone occurring just in the South and entering Indonesia region is relatively rare, but the event will significantly affect to increase in rainfall in some parts of Indonesia and often cause flood disaster.

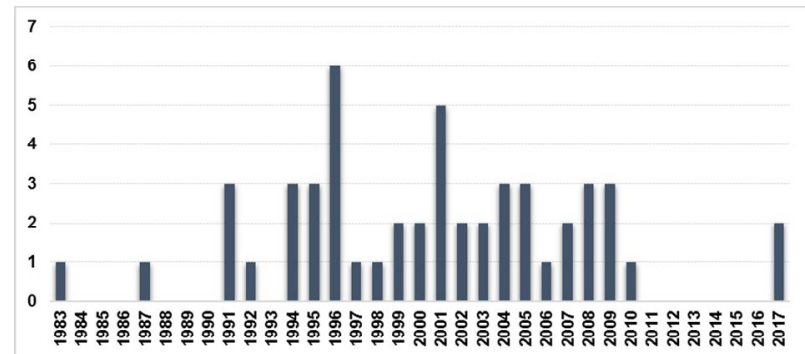

Fig. 3. The number of tropical cyclone events per year in southern Indonesia during 1983-2017.

Within 35 years' period, on average there are 1-2 tropical cyclones in Southern Indonesia. Figure 3 shows the number of tropical cyclones per year in southern Indonesia from 1983 to 2017. As shown in Figure 3, by average there are 1-2 tropical cyclones in southern Indonesia annually, with the highest number of tropical cyclones event occurring in the year 1996 (6 tropical cyclones).

Based on the pattern of the annual number of tropical cyclones event, the years of 1994-2010 considerably are the years with the highest number of tropical cyclones event compared to other years. On average, about 2-3 occurrences of tropical cyclones are almost always occurring in that period per year.

From 2011 to 2016, there are no recorded tropical cyclone events in southern Indonesia. However, that condition does not sum up the occurrences of tropical cyclone formed in the southern hemisphere. It is more likely, during 2011-2016 there were no tropical cyclones that growth or passed in southern Indonesia $\left(0^{\circ}-10^{\circ} \mathrm{S}\right)$.

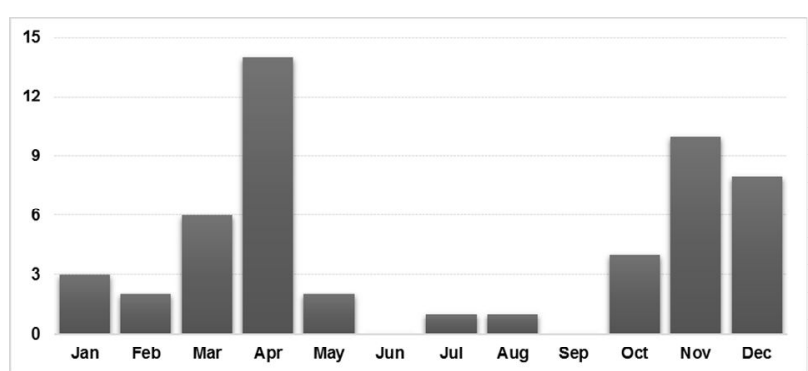

Fig. 4. The number of tropical cyclone events per month in southern Indonesia during 1983-2017.

The monthly pattern as shown in Figure 4 shows that tropical cyclones occur more frequently in NovemberApril. The occurrence of tropical cyclones in MayOctober tends to be minimal when compared to the annual pattern.

Of the total 51 tropical cyclones that happened during the period 1983-2017 in southern Indonesia, 14 of them occurred in April. Tropical cyclones Alistair (2001), Bonnie (2002) and Kirrily (2009) which occurred in the Banda and Arufuru Sea were the examples of tropical cyclones that happened in April. Inigo tropical cyclones that crossed the Flores Sea and continue moved south-southwest in 2003 also occurred in April.

Although several occurrences of tropical cyclones are formed in Indonesian waters or even into Indonesian territory, their low-pressure values are still quite high when compared to other regions. As shown in Figure 5, the spatial distribution of tropical cyclone pressure values during the years $1983-2017$ at latitude $0^{\circ}-10^{\circ} \mathrm{S}$ tends to be higher when compared to other pressure values in $10^{\circ} \mathrm{S}-20^{\circ} \mathrm{S}$. 


\section{TROPICAL CYCLONES PRESSURE IN SOUTHERN INDONESIA 1982-2017}

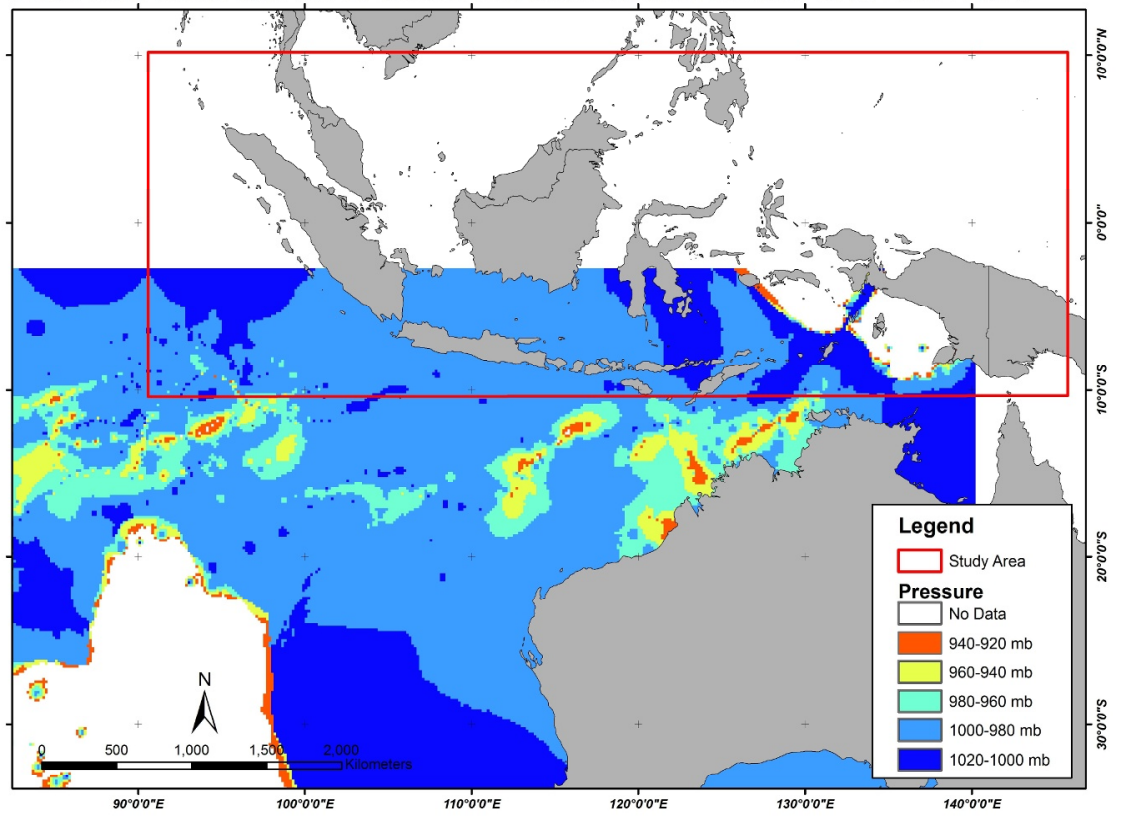

Fig. 5. The central pressure of tropical cyclones in southern Indonesia during 1983-2017.

Generally, tropical cyclones during the period 19832017 in southern Indonesia have a central pressure value not less than $960 \mathrm{hPa}$. The tropical cyclone, central pressure value in southern Indonesia, will reach its lowest value at latitude $10^{\circ} \mathrm{S}-20^{\circ} \mathrm{S}$ with central pressure value between $960-920 \mathrm{hPa}$. The territory of the Indonesian archipelago which is closest to the tropical cyclone lowest pressure in that period is Nusa Tenggara islands. As can be seen from Figure 5, the sea between Nusa Tenggara islands and the Australian continent is an area with shallow central pressure values.

Among the Cyclones there are at least 9 Tropical Cyclones that enter into Indonesian territory: Esther Tropical Cyclone (18 - 20 December 1983), Kay Tropical Cyclone (8-17 April 1987), Alistair Tropical
Cyclone (15 - 23 April 2001), Bonnie Tropical Cyclone (7 - 15 April 2002), Inigo Tropical Cyclone (March 31 April 8, 2003), Ilsa Tropical Cyclone (March 15-24, 2009), Kirrily Tropical Cyclone (April 17 to May 1, 2009), Dahlia Tropical Cyclone (November 26 December 4, 2017) and Cempaka Tropical Cyclone (November 26 - December 1, 2017).

The Tropical Cyclone spatial distribution that goes into the territory of Indonesia is represented in Figure 6. Tropical Cyclones occurring in the Southern Sea of Indonesia generally have a lifespan of 8-9 days. The longest lasting Tropical Cyclone is the Kirrily Tropical Cyclone that occurred in 2009 with a duration of 14 days.

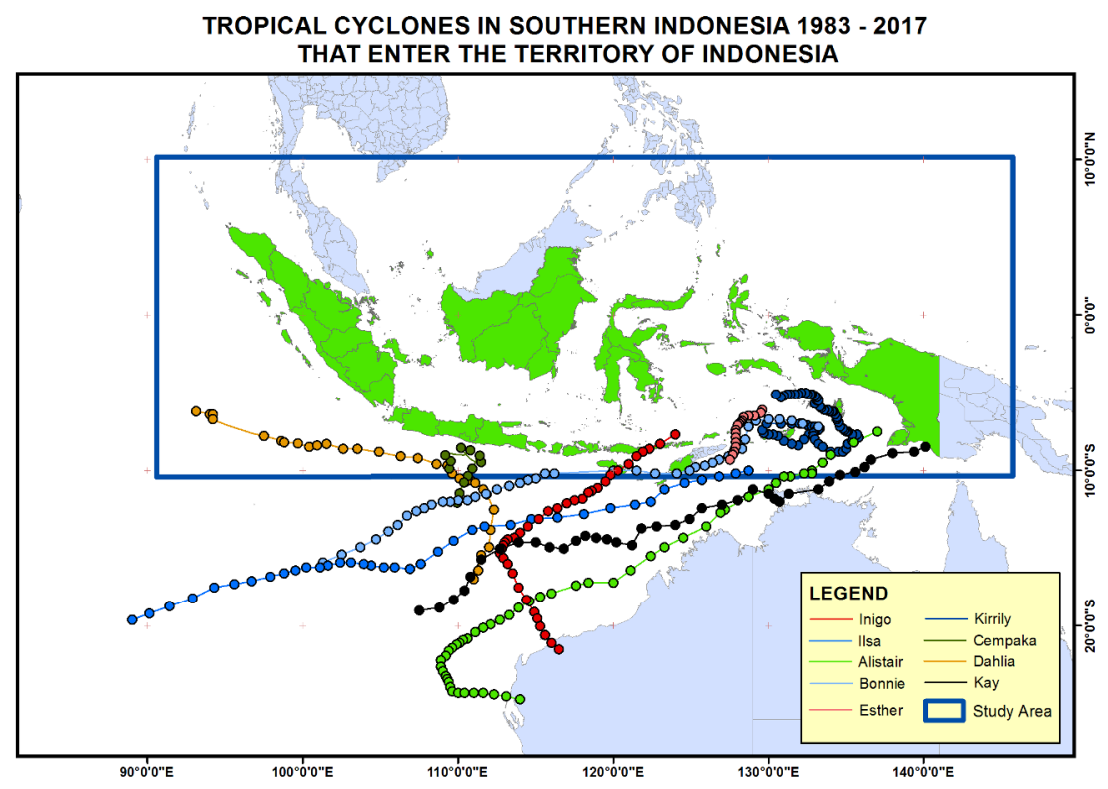

Fig. 6. Tropical cyclones in Southern Indonesia that enter the Territory of Indonesia. 
Table 1. Tropical Cyclones that enter the territory of Indonesia

\begin{tabular}{|c|c|c|c|c|c|c|c|c|c|c|c|}
\hline No. & Name & $\begin{array}{l}\text { Date } \\
\text { Begin }\end{array}$ & $\begin{array}{l}\text { Date } \\
\text { End }\end{array}$ & $\begin{array}{c}\text { Lat } \\
\text { Begin }\end{array}$ & $\begin{array}{l}\text { Lon } \\
\text { Begin }\end{array}$ & $\begin{array}{l}\text { Lat } \\
\text { End }\end{array}$ & $\begin{array}{l}\text { Lon } \\
\text { End }\end{array}$ & $\begin{array}{c}\text { Life } \\
\text { Span } \\
\text { (Days) }\end{array}$ & $\begin{array}{l}\text { Lowest } \\
\text { Pressure }\end{array}$ & $\begin{array}{c}\text { Lat } \\
\text { Lowest }\end{array}$ & $\begin{array}{l}\text { Lon } \\
\text { Lowest }\end{array}$ \\
\hline 1 & Esther & 18-Dec-83 & 20-Dec-83 & -6.1 & 129.6 & -9.3 & 127.5 & 2 & 992 & -7.6 & 127.9 \\
\hline 2 & Kay & 08-Apr-87 & 17-Apr-87 & -8.5 & 140.1 & -19.0 & 107.5 & 9 & 987 & -10.7 & 133.9 \\
\hline 3 & Alistair & 15-Apr-01 & 23-Apr-01 & -7.5 & 137.0 & -24.7 & 114.0 & 8 & 975 & -14.9 & 123.3 \\
\hline 4 & Bonnie & $07-A p r-02$ & $15-A p r-02$ & -7.2 & 133.2 & -15.9 & 101.3 & 8 & 985 & 116.2 & 985.0 \\
\hline 5 & Inigo & $\begin{array}{c}\text { 31-Mar- } \\
03\end{array}$ & 08-Apr-03 & -7.7 & 124.0 & -21.5 & 116.5 & 8 & 955 & -15.6 & 97.9 \\
\hline 6 & Ilsa & $\begin{array}{c}\text { 15-Mar- } \\
09\end{array}$ & 24-Mar-09 & -10.0 & 128.7 & -19.6 & 89.0 & 9 & 980 & -16.8 & 134.9 \\
\hline 7 & Kirrily & 17-Apr-09 & 01-Мay-09 & -7.3 & 133.3 & -5.1 & 130.5 & 14 & 999 & -7.4 & 110.5 \\
\hline 8 & Dahlia & $\begin{array}{c}\text { 26-Nov- } \\
17\end{array}$ & 04-Dec-17 & -6.2 & 93.1 & -17.0 & 111.0 & 8 & 985 & -10.7 & 110.8 \\
\hline 9 & Cempaka & $\begin{array}{c}\text { 26-Nov- } \\
17\end{array}$ & $12 / 01 / 2017$ & -9.9 & 109.4 & -12.1 & 109.9 & 5 & 998 & -8.7 & 110.8 \\
\hline
\end{tabular}

Table 1 shows the lifespan, location and lowest pressure data of Tropical Cyclones entering into Indonesian territory. Among the nine Tropical Cyclones, there are several Tropical Cyclones across the Indonesian archipelago, such as Esther Tropical Cyclone in 1983, Inigo Tropical Cyclone in 2003, Ilsa Tropical Cyclone in 2009 and the last Kirrily Tropical Cyclone in 2009 that crossed the archipelago of Aru, Maluku.

Tropical Cyclone events that are entering into Indonesian territory have a significant impact on the increase of rainfall and causing floods [15], for example, Tropical Cyclone Cempaka that occurred on November 26 to December 1, 2017, in southern sea of Yogyakarta Region and surrounding areas.

The peak of the Cempaka Tropical Cyclone occurred on November 28, 2017, and its center is very close to the southern coast of D. I. Yogyakarta Province so that causing floods in Bantul, Gunungkidul, Wonogiri, and Pacitan districts. Rainfall spatial distribution in D.I. Yogyakarta and surrounding area on November 28, 2017, shown in Figure 7.
Based on Figure 7 it can be seen that the Cempaka Tropical Cyclone has caused the occurrence of extreme rainfall in the Yogyakarta region and surrounding area with the intensity of rainfall up to $175-250 \mathrm{~mm} /$ day. Rainfall with the highest intensity of $225-250 \mathrm{~mm} /$ day generally occurs in the most of Gunungkidul Regency. Due to this extreme rainfall, Gunungkidul Regency can be hit by floods although this region is generally a hilly area.

Figure 8 represents the daily historical rainfall pattern on November in Gunungkidul Regency during the period 2009 - 2017. From the picture, it can be seen that the Cempaka Tropical Cyclone on the south coast of D.I. Yogyakarta Province has caused the extreme rainfall in Gunungkidul Regency with the average intensity of the rainfall in Gunungkidul Regency reached 225 $\mathrm{mm}$ /day or increased $750 \%$ when compared with a historical average which only ranges from 10-30 $\mathrm{mm} /$ day.

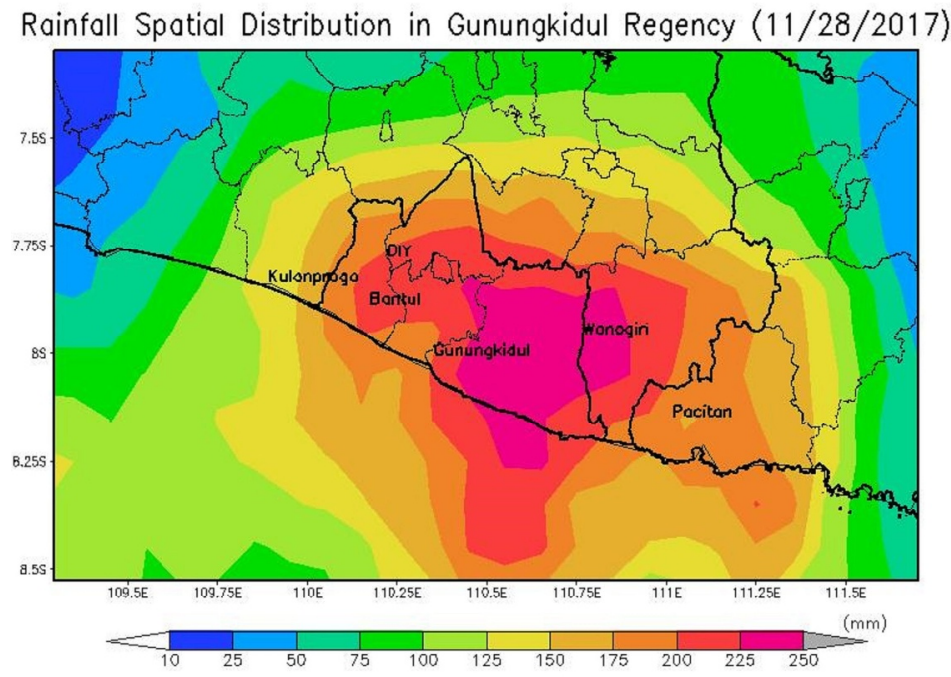

Fig. 7. Rainfall Spatial Distribution in the Yogyakarta region and surrounding area. 


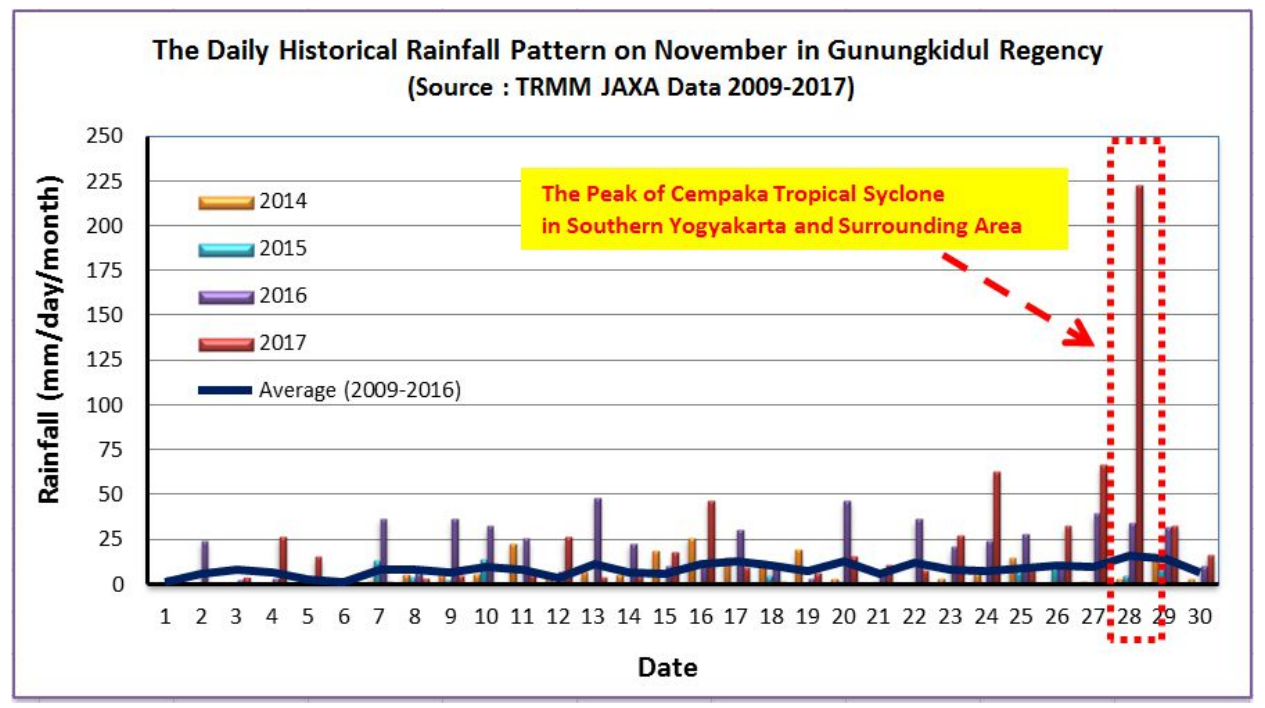

Fig. 8. The daily historical rainfall pattern on November in Gunungkidul Regency (Source: TRMM JAXA data 2009-2017).

\section{Conclusion}

During 1983-2017, there have been 51 tropical cyclones located in latitude $0^{\circ}-10^{\circ} \mathrm{S}$ (Southern Indonesia). A Tropical cyclone in that region is predominantly occurring in November-April with the record of most incidence data in April (14 tropical cyclones) and with the lifetime about 7-8 days. Tropical cyclones in southern in latitude $0^{\circ}-10^{\circ} \mathrm{S}$ higher central pressure value (above $960 \mathrm{hPa}$ ) compared to the central pressure of tropical cyclone in latitude $10^{\circ}-20^{\circ} \mathrm{S}(920-960 \mathrm{hPa})$.

There are 9 tropical cyclones that grew or moved very close to the Indonesian archipelago in 1983-2017, with the last two cyclones (Dahlia and Cempaka) occurring at the end of 2017.

Both cyclones moved very close to the southern regions of Java Island such as D.I. Yogyakarta Province. This caused a significant increase in rainfall intensity in Gunungkidul, Yogyakarta. From the analysis of historical rainfall data, the highest rainfall in Gunungkidul at Cempaka Tropical Cyclone hit 225 $\mathrm{mm}$ /day in 28th November 2017. This value is an extreme event with an increase in rainfall up to $750 \%$ of the historical average.

\section{References}

1. N.S. Haryani, and A. Zubaidah, " The dynamics of tropical cyclones in Southeast Asia use remote sensing data" Widya Scientific Magazine, vol.324, pp.54-58, Sep-Oct. 2012.

2. P.J. Webster, G.J. Holland, J.A. Curry, and H.-R. Chang, "Changes in tropical cyclone number, duration and intensity in a warming environment," Science, vol.309 (5742), pp.1844-1846, Sep. 2005.

3. Y. Kuleshov, R. Fawcett. L. Qi, B. Trewin, D. Jones, J. McBride, and H. Ramsey, "Trends in tropical cyclones in the South Indian Ocean and the South Pacific Ocean," Journal of Geophysical Research, vol.115(D01101), pp.1-9, Jan. 2010.
4. N. Nicholls, C. Landsea, and J. Gill, "Recent trends in Australian region tropical cyclone activity," Meteorology and Atmospheric Physics, vol.65, pp.197-205, Sep. 1998.

5. B.A. Harper, S.A. Stroud,M. McCormack, and S. West, "A review of historical tropical cyclone intensity in northwestern Australia and implications for climate change trend analysis," Australian Meteorological Magazine, vol.57, pp.121-141, Jun. 2008.

6. Y. Kuleshov, L.Qi, R. Fawcett, and D. Jones, "On tropical cyclone activity in the Southern Hemisphere; Trends and the ENSO connection," Geophysical Research Letters, vol.35 (14), L14S08, pp.1-5, Jul. 2008.

7. C.-H. Ho, J.-H. Kim, J.-H. Jeong, H.-S. Kim, and D. Chen, "Variation of tropical cyclone activity in the South Indian Ocean: El Nino-Southern Oscillation and Madden-Julian Oscillation effects," Journal of Geophysical Research, vol.111 (D22101), pp.1-9, Nov. 2006.

8. Renggono, F and D. Syaifullah. "Meteorological Assessment of Banjir Bandang Disaster in Wasior, West Papua ." Meteorology and Geophysics Journal , vol.12 (1), pp.33-41. 2011.

9. D. Syaifullah. "Rainfall conditions in the Jakarta flood event and analysis of air conditions over the Jakarta area from January to February 2013." Journal of Science \& Weather Modification Technology, vol.14 (1), pp.19-26. 2013.

10. A. Suryantoro, " The TRMM satellite Radar precipitation for monitoring rainfall during tropical cyclones " in National Seminar on Application of Science and Technology, 2008, pp.7-17.

11. J.B. Elsner, J.P. Kossin, and T.H. Jagger, "The increasing intensity of the strongest tropical cyclones," Nature, vol.455, pp.92-95, Sep. 2008.

12. K.R. Knapp, M.C. Kruk, D.H. Levinson, H.J Diamond, and C.J. Neumann, "The International 
Best Track Archive for Climate Stewardship (IBTrACS): Unifying tropical cyclone data," Bulletin of the American Meteorological Society, vol.91 (3), pp.363-376, Mar. 2010.

13. K. Emanuel, "Increasing destructiveness of tropical cyclones over the past 30 years," Nature, vol.436, pp.686-688, Aug. 2005.
14. T.R. Knutson, J.L. Mc Bride, J. Chan, K. Emanuel, G. Holland, C. Landsea, I. Held, J.P. Kossin, A.K. Srivastava, and M. Sugi, "Tropical cyclone and climate change," Nature Geoscience, vol.3, pp.157163, Feb. 2010.

15. Nurhamidah, N., B. Rusman, et al. (2017). "Social, economic and environmental perspectives of flood assessment on delta lowland." International Journal of Civil Engineering and Technology: 966-978. 